\title{
Cation Transport and Its Altered Regulation in Human Stomatocytic Erythrocytes
}

\author{
P. O. DUTCHER, G. B. SEGEL, ${ }^{(2)}$ S. A. FEIG, D. R. MILlER, AND M. R. KLEMPERER
}

\begin{abstract}
Departments of Pediatrics and Medicine, University of Rochester School of Medicine and Dentistry, Rochester, New York, The Gwynne Hazen Cherry Memorial Laboratory, The Department of Pediatrics, UCLA School of Medicine, Los Angeles, California, and the Department of Pediatrics, Cornell University Medical College, New York,
\end{abstract} New York, USA

\section{Extract}

Cation transport in a population of stomatocytic red blood cells $(\mathrm{RBC})$ is abnormal in the following respects. First, active transport against a gradient, defined as the nonisotopic net accumulation of $\mathrm{Na}^{+}$or loss of $\mathrm{K}^{+}$induced by $0.1 \mathrm{mM}$ ouabain, is markedly elevated ( 7.3 and $6.3 \mathrm{mEq} /$ liter cells/hr for $\mathrm{Na}^{+}$and $\mathrm{K}^{+}$, respectively), but the $\mathrm{Na}^{+}: \mathrm{K}^{+}$active transport ratio is normal. Apparent uncoupling of the $\mathrm{Na}^{+}$and $\mathrm{K}^{+}$isotope transport is due to disproportionately increased ouabain-sensitive ${ }^{24} \mathrm{Na}^{+}{ }^{23} \mathrm{Na}^{+}$exchange $(32.7 \mathrm{mEq}$ /liter cells/hr), which is measured as a portion of ${ }^{24} \mathrm{Na}^{+}$isotope efflux. Second, cation transport is unresponsive to variations in internal $\mathrm{Na}^{+}$concentration but decreases with decreasing extracellular $\mathrm{Na}^{+}$.

\section{Speculation}

In the family we have studied, the clinical disorder, hereditary stomatocytosis, has been shown to be an autosomal dominant trait. The disorder may be due, therefore, to the transcription of an abnormal membrane protein which leads to altered shape, abnormal cation permeability, and reduced cell survival in vivo. The abnormal protein may be structural, leading to the shape alteration, and functional, leading to the alteration in permeability and transport. The abnormality, hereditary stomatocytosis, is a heterogeneous group of disorders; hence, the observations in this family may not reflect the specific membrane protein defect in all cases.

Hereditary stomatocytosis is a dominant pleomorphic disorder which often results in hemolytic anemia (10). Some stomatocytic $\mathrm{RBC}$ have been characterized by abnormalities in monovalent cation content and transport $(10,12)$. The stomatocytic RBC in two such families demonstrated a marked increase in $\mathrm{Na}^{+}$and $\mathrm{K}^{+}$ transport with apparent uncoupling of the normal $3: 2 \mathrm{Na}^{+}: \mathrm{K}^{+}$ transport ratio $(10,12)$. R BC from three affected patients studied by Miller et al. (10) contained a moderately increased intracellular $\mathrm{Na}^{+}(20.9 \mathrm{mEq} /$ liter cells $)$, slightly decreased intracellular $\mathrm{K}^{+}$ (86.4 mEq/liter cells), and normal intracellular $\mathrm{Na}^{+}$plus $\mathrm{K}^{+}$ content (107 mEq/liter cells). In one of these patients, $\mathrm{Na}^{+}$efflux was elevated, $\mathrm{K}^{+}$influx was normal, and the $\mathrm{Na}^{+}: \mathrm{K}^{+}$transport ratio was strikingly abnormal (26:1). We have had the opportunity to study further the $\mathrm{Na}^{+}$and $\mathrm{K}^{+}$transport characteristics of the $\mathrm{RBC}$ from another affected member of this family.

The data indicate that in these particular stomatocytes, cation transport is abnormal in the following respects. First, active transport against a gradient, defined as the nonisotopic net accumulation of $\mathrm{Na}^{+}$or loss of $\mathrm{K}^{+}$induced by $0.1 \mathrm{mM}$ ouabain, is markedly elevated, but the $\mathrm{Na}^{+}: \mathrm{K}^{+}$active transport ratio is normal. Apparent uncoupling of $\mathrm{Na}^{+}$and $\mathrm{K}^{+}$isotope transport is due to disproportionately increased ${ }^{24} \mathrm{Na}^{+}{ }^{23} \mathrm{Na}^{+}$exchange measured as a portion of ${ }^{24} \mathrm{Na}^{+}$isotope efflux. Second, cation transport is unresponsive to variations in internal $\mathrm{Na}^{+}$concentra- tion but decreases with decreasing extracellular $\mathrm{Na}^{+}$. This, of course, does not occur in normal RBC where transport is responsive to variation in internal $\mathrm{Na}^{+}$but unaffected by changing the external $\mathrm{Na}^{+}$concentration.

\section{METHODS}

RBC PREPARATION

Blood samples from patient $J M$ and normal volunteers were obtained by venipuncture and anticoagulated with preservativefree sodium heparin $(0.1 \mathrm{mg} / \mathrm{ml})$. The cells were sedimented at $1,500 \mathrm{~g}$ and the plasma and buffy coat were removed. The RBC were then washed twice and resuspended to a packed cell volume of $40 \%$ in Krebs-Henseleit bicarbonate (K HB) buffer (sodium 145 $\mathrm{mEq} /$ liter and potassium $5.2 \mathrm{mEq} /$ liter), $\mathrm{pH} \mathrm{7.4,} \mathrm{containing} 10$ $\mathrm{mM}$ glucose and $1 \mathrm{~g} / 100 \mathrm{ml}$ bovine serum albumin. The RBC were incubated in air plus $5 \% \mathrm{Co}_{2}$ as described previously (2).

\section{ISOTOPE AND NET (ACTIVE) TRANSPORT AND EXCHANGE}

Measurements of ${ }^{24} \mathrm{Na}^{+}$exodus and ${ }^{42} \mathrm{~K}^{+}$accumulation were performed and calculated as reported previously (2). Total ${ }^{24} \mathrm{Na}^{+}$ transport represents the exodus of ${ }^{24} \mathrm{Na}^{+}$from prelabeled $\mathrm{RBC}$ into the extracellular medium (pathways $l+2+3$ in Fig. 1). Ouabain-sensitive isotope transport is that proportion of the total which is inhibitable by $0.1 \mathrm{mM}$ ouabain (pathways $l+2$ ). This measurement has two components: active transport (pathway I) and ouabain-sensitive exchange (pathway 2). Thus, ouabain-sensitive ${ }^{24} \mathrm{Na}$ efflux is not a measure of active sodium transport. Active cation transport (pathway $I$ ) is a nonisotopic measurement and is determined by the intracellular gain of $\mathrm{Na}^{+}$(pathway 4) when pathway $l$ is inhibited by $0.1 \mathrm{mM}$ ouabain. Ouabain-sensitive exchange (pathway 2) is calculated as the difference between ouabain-sensitive isotope transport and active transport. The residual isotope transport in the presence of $0.1 \mathrm{mM}$ ouabain represents ouabain-independent exchange (pathway 3). For simplicity, only $\mathrm{Na}^{+}$movement is shown in Figure $1 . \mathrm{K}^{+}$behaves similarly in the opposite direction.

\section{ACTIVE TRANSPORT AT VARIOUS INTRACELLULAR $\mathrm{Na}^{+}$ CONCENTRATIONS}

Elevation of the intracellular $\mathrm{Na}^{+}$content was achieved by incubating the $\mathrm{RBC}$ at $37^{\circ}$ in $\mathrm{KHB}$ containing $10 \mathrm{mM}$ glucose, 200 $\mathrm{mg} / 100 \mathrm{ml}$ albumin, and amphotericin B (obtained from Squibb as Fungizone) at a concentration of $5 \mu \mathrm{g} / \mathrm{ml}$ as described by Blum et al. (1). Increasing the time from $30 \mathrm{~min}$ to $4 \mathrm{hr}$ of such incubations allowed the accumulation of additional intracellular $\mathrm{Na}^{+}$. The amphotericin B was removed by washing twice with KHB containing glucose and $1 \mathrm{~g} / 100 \mathrm{ml}$ albumin followed by washing and resuspension in $\mathrm{KHB}$ containing glucose and $200 \mathrm{mg} / 100 \mathrm{ml}$ 


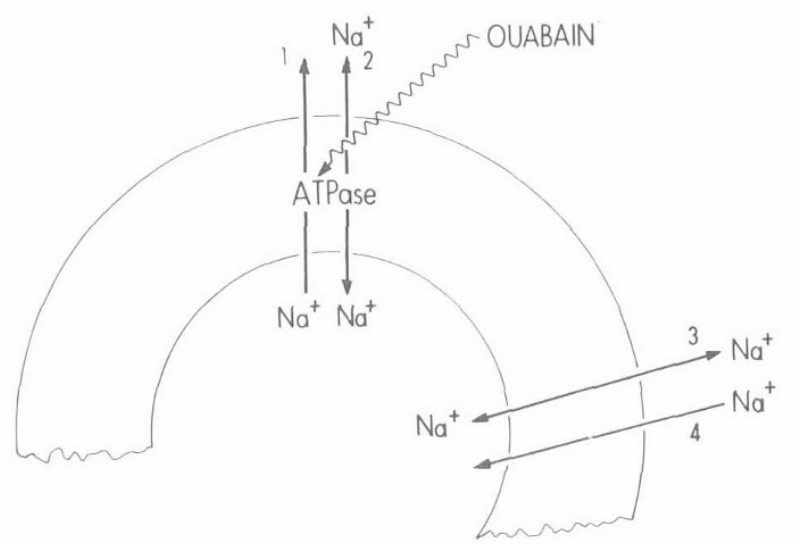

Fig. 1. Schematic representation of $\mathrm{Na}^{+}$movements across the red blood cell (RBC) membrane. Total ${ }^{24} \mathrm{Na}^{+}$transport measures the total ${ }^{24} \mathrm{Na}^{+}$ passing from prelabeled $\mathrm{RBC}$ into the extracellular medium along pathways $l+2+3$. Ouabain-sensitive ${ }^{24} \mathrm{Na}^{+}$transport (pathways $l+2$ ) is that portion of the total which is inhibitable by $0.1 \mathrm{mM}$ ouabain and includes two components: active transport (pathway l) and ouabain-sensitive exchange (pathway 2). Active transport (pathway l) is a nonisotopic measurement and is determined as the intracellular accumulation of ${ }^{23} \mathrm{Na}^{+}$ (pathway 4 ) when pathway $l$ is inhibited by $0.1 \mathrm{mM}$ ouabain. Ouabain-sensitive exchange (pathway 2) is calculated as the difference between ouabain-sensitive ${ }^{24} \mathrm{Na}^{+}$transport (pathways $l+2$ ) and active transport (pathway 1). The difference between total ${ }^{24} \mathrm{Na}^{+}$transport (pathways $l+2+3$ ) and ouabain-sensitive ${ }^{24} \mathrm{Na}^{+}$transport (pathways $l+2$ ) represents ouabain-independent exchange (pathway 3 ).

albumin (16). To decrease the intracellular sodium content of stomatocytic RBC, the cells were incubated in a modified KHB containing high $\mathrm{K}^{+}(140 \mathrm{mEq} /$ liter $)$ and low $\mathrm{Na}^{+}(5 \mathrm{mEq} /$ liter $)$ until the desired intracellular $\mathrm{Na}^{+}$was obtained. These cells were quickly washed three times with a standard KHB, resuspended, and incubated for measurement of active transport.

\section{ACTIVE TRANSPORT AT VARIOUS EXTRACELLULAR $\mathrm{Na}^{+}$ CONCENTRATIONS}

Variation in the $\mathrm{Na}^{+}$gradient across the $\mathrm{RBC}$ membrane was produced by lowering the extracellular $\mathrm{Na}^{+}$concentration. Modified $\mathrm{KHB}$ containing $10 \mathrm{mM}$ glucose and $1 \mathrm{~g} / 100 \mathrm{ml}$ albumin was prepared in which the $\mathrm{Na}^{+}$concentration was $15,25,60,100$, and $145 \mathrm{mEq} /$ liter buffer. The diminished $\mathrm{NaCl}$ in each buffer was replaced by equiosmolar succinylcholine chloride which neither penetrated RBC nor affected transport. Normal and stomatocytic RBC were washed three times in the appropriate buffer and resuspended at a packed cell volume of approximately $40 \%$. The $\mathrm{RBC}$ suspensions were then incubated at $37^{\circ}$ in the presence and absence of ouabain, and timed samples were taken to determine active cation transport at each extracellular $\mathrm{Na}^{+}$concentration.

\section{LACTATE PRODUCTION}

Samples for lactate determination were removed periodically from the incubating cell suspensions and deproteinized by adding to 2 volumes $6 \%$ perchloric acid at $4^{\circ}$. The supernatant solution was removed and neutralized with $5 \mathrm{M} \mathrm{K}_{2} \mathrm{CO}_{3}$ and frozen for later analysis of lactate (9). Ouabain-sensitive lactate production was calculated from measurements of lactate production in the presence and absence of $0.1 \mathrm{mM}$ ouabain.

\section{STATISTICAL ANALYSIS}

Slopes of regression lines were determined by the method of least squares, and means and standard deviations were performed by standard statistical methods (7).

\section{RESULTS}

\section{ISOTOPE AND ACTIVE TRANSPORT AND EXCHANGE}

Abnormalities in $\mathrm{Na}^{+}$and $\mathrm{K}^{+}$transport and exchange in these stomatocytes are shown in Table 1 . Total ${ }^{24} \mathrm{Na}^{+}$transport is more than 20 times normal, $60 \mathrm{mEq} /$ liter cells/hr, compared with 2.9 $\mathrm{mEq} /$ liter cells/hr. Total ${ }^{42} \mathrm{~K}^{+}$transport is only $4-5$ times normal, $7.5 \mathrm{mEq} /$ liter cells $/ \mathrm{hr}$, compared with $1.7 \mathrm{mEq} / \mathrm{liter}$ cells $/ \mathrm{hr}$. Total isotope transport includes two components: ouabain-sensitive isotope transport and ouabain-independent exchange. Ouabain-sensitive ${ }^{24} \mathrm{Na}^{+}$transport is also 20 times normal, 40.0 $\mathrm{mEq} /$ liter cells/hr, compared with $2.0 \mathrm{mEq} /$ liter cells $/ \mathrm{hr}$. Ouabain-sensitive ${ }^{42} \mathrm{~K}^{+}$transport is 5 times normal, $6.5 \mathrm{mEq} /$ liter cells/hr, compared with $1.3 \mathrm{mEq} /$ liter cells/hr. The ouabainindependent exchange follows a pattern similar to the total isotope transport and ouabain-sensitive isotope transport. Ouabainindependent exchange of ${ }^{24} \mathrm{Na}^{+}{ }^{23} \mathrm{Na}^{+}$is $20.0 \mathrm{mEq} /$ liter cells $/ \mathrm{hr}$, compared with normal, 0.9 ; ouabain-independent exchange of ${ }^{42} \mathrm{~K}^{+}{ }^{39} \mathrm{~K}^{+}$is $1.0 \mathrm{mEq} /$ liter cells $/ \mathrm{hr}$, compared with 0.4 .

In order to determine active (net) transport against a gradient. the rate of ouabain-induced gain of $\mathrm{Na}^{+}$and loss of $\mathrm{K}^{+}$were measured. Using this technique, the active transport of either $\mathrm{Na}^{+}$ $(7.3 \mathrm{mEq} /$ liter cells $/ \mathrm{hr})$ or $\mathrm{K}^{+}(6.3 \mathrm{mEq} /$ liter cells $/ \mathrm{hr})$ is approximately 5 times normal. Consequently, the ratio of $\mathrm{Na}^{+}: \mathrm{K}^{+}$ transport is 1.2, which is identical with the ratio we obtained in normal cells. Ouabain-sensitive ${ }^{24} \mathrm{Na}^{+}{ }^{23} \mathrm{Na}^{+}$exchange is the difference between ouabain-sensitive ${ }^{24} \mathrm{Na}^{+}$transport and active $\mathrm{Na}^{+}$transport. This exchange is markedly elevated, $32.7 \mathrm{mEq} /$ liter cells/hr, compared with normal, 0.6. The magnitude of ouabain-sensitive ${ }^{24} \mathrm{Na}^{+}{ }^{23} \mathrm{Na}^{+}$exchange accounts for the disproportionate elevation of the ouabain-sensitive ${ }^{24} \mathrm{Na}^{+}$exodus. since ouabain-sensitive ${ }^{42} \mathrm{~K}+{ }^{39} \mathrm{~K}+$ exchange is near normal, 0.2 $\mathrm{mEq} /$ liter cells/.hr, as compared with normal, $0.1 \mathrm{mEq} /$ liter cells/hr.

\section{ACTIVE TRANSPORT AT VARIOUS INTRACELLULAR $\mathrm{Na}^{+}$ CONCENTRATIONS}

Figure $2 A$ shows the response of active $\mathrm{Na}^{+}$transport to variation of intracellular $\mathrm{Na}^{+}$concentration in normal and stomatocytic $\mathrm{RBC}$. Active $\mathrm{Na}^{+}$transport was measured at intracellular $\mathrm{Na}^{+}$concentrations of 6-45 mEq/liter cells. While normal $\mathrm{RBC}$ increase transport to a maximum of $5 \mathrm{mEq} /$ liter cells/ $\mathrm{hr}$ at an intracellular $\mathrm{Na}^{+}$of approximately $30 \mathrm{mEq} /$ liter cells, the stomatocytes have a greater maximal transport rate $(7-8 \mathrm{mEq} /$ liter cells/hr) which does not change with alteration of the intracellular $\mathrm{Na}^{+}$. Figure $2 B$ demonstrates a similar response of active $\mathrm{K}^{+}$transport to varying intracellular $\mathrm{Na}^{+}$concentration. Active $\mathrm{K}^{+}$transport, 6-7 $\mathrm{mEq} /$ liter cells $/ \mathrm{hr}$, is greater than the normal maximal $\mathrm{K}^{+}$transport $3.8 \mathrm{mEq} /$ liter cells $/ \mathrm{hr}$, and is little affected by alteration of the internal $\mathrm{Na}^{+}$concentration. Values for active transport below an intracellular $\mathrm{Na}^{+}$of $6 \mathrm{mEq} /$ liter cells could not be determined in the stomatocytes because the low intracellular $\mathrm{Na}^{+}$concentrations could not be maintained.

\section{ACTIVE TRANSPORT VS. EXTRACELLULAR Na+ CONCENTRATION}

The effect of decreasing the extracellular $\mathrm{Na}^{+}$concentration on active $\mathrm{Na}^{+}$and $\mathrm{K}^{+}$transport is shown in Figure 3, $A$ and $B$, respectively. In the stomatocytic $\mathrm{RBC}$, both active $\mathrm{Na}^{+}$and $\mathrm{K}^{+}$ transport were diminished from 9.6 and $7.7 \mathrm{mEq} /$ liter cells/ $\mathrm{hr}$ to 4.2 and $3.3 \mathrm{mEq} /$ liter cells $/ \mathrm{hr}$, respectively, by lowering the extracellular $\mathrm{Na}^{+}$concentration from $140 \mathrm{mEq} /$ liter to $20 \mathrm{mEq} /$ liter. However, active $\mathrm{Na}^{+}$and $\mathrm{K}^{+}$transport in normal $\mathrm{RBC}$ was virtually unaffected by a similar reduction in the extracellular $\mathrm{Na}^{+}$ concentration.

\section{LACTATE PRODUCTION}

Ouabain-sensitive lactate production is a measure of the metabolic energy devoted to active transport $(2,18)$. Figure 4 demon- 
Table 1. $\mathrm{Na}^{+}$and $\mathrm{K}^{+}$movements in normal and stomatocvtic red blood cells $(R B C)^{1}$

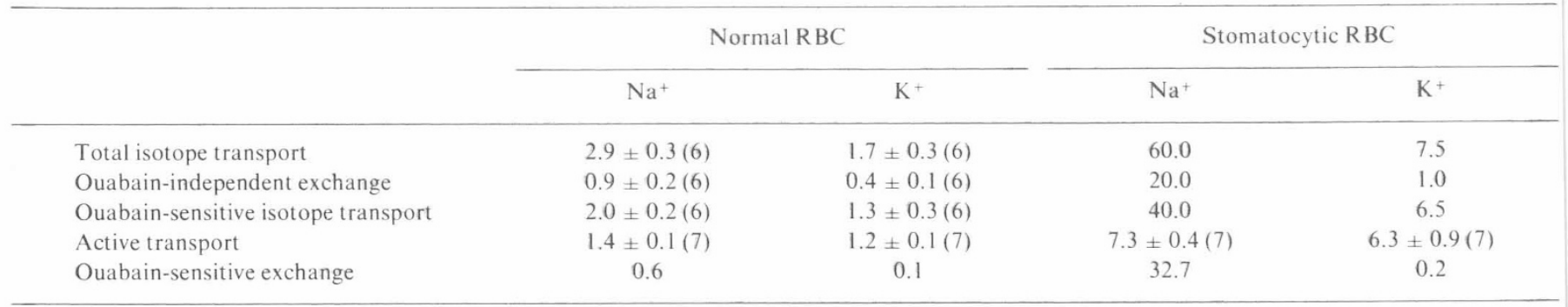

${ }^{1}$ Values represent the mean $\pm \mathrm{SD}$ in milliequivalents per liter cells per $\mathrm{hr}$. The number of measurements is shown in parentheses.
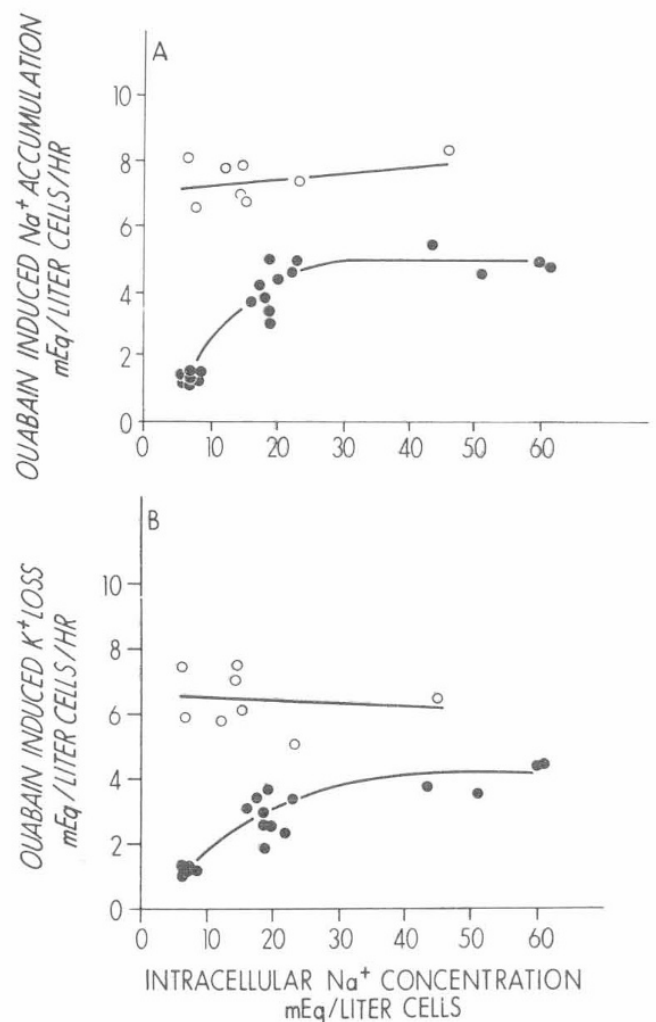

Fig. 2. The effect of various intracellular $\mathrm{Na}^{+}$concentrations on active transport, that is, the net intracellular accumulation of $\mathrm{Na}^{+}(A)$, and loss of $\mathrm{K}^{+}(B)$, induced by $0.1 \mathrm{mM}$ ouabain. Each point represents the mean of duplicate measurements. normal erythrocytes; O, stomatocytes.

strates the relationship between active $\mathrm{Na}^{+}$transport and the corresponding energy requirement. In normal $\mathrm{RBC}$, the lactate production required for the transport of $3 \mathrm{mEq} \mathrm{Na} /$ liter cells $/ \mathrm{hr}$ is approximately $1 \mathrm{mM} /$ liter cells/hr. The markedly elevated active transport rate in these stomatocytes permits graphic extension of the normal relationship between transport and metabolism.

\section{DISCUSSION}

$\mathrm{Na}^{+}$and $\mathrm{K}^{+}$transport in the human erythrocyte is responsible for the maintenance of a low intracellular $\mathrm{Na}^{+}$concentration and a high intracellular $\mathrm{K}^{+}$concentration. This transport is mediated by an ATPase system located in the erythrocyte membrane $(15,17)$. $\mathrm{Na}^{+}$and $\mathrm{K}^{+}$transport opposes the respective cation gradients, and usually occurs in a ratio of approximately $3: 2\left(\mathrm{Na}^{+}: \mathrm{K}^{+}\right)(6,8,13)$. The dissociation of $\mathrm{Na}^{+}$and $\mathrm{K}^{+}$transport has never been satisfactorily documented in human erythrocytes. Pump dissociation secondary to substrate depletion (2) was subsequently shown to be an artifact of increasing ouabain-sensitive $\mathrm{K}^{+}-\mathrm{K}^{+}$exchange in depleted $\mathrm{RBC}(14,16)$. The ratio of $\mathrm{Na}^{+}$to $\mathrm{K}^{+}$transport in the
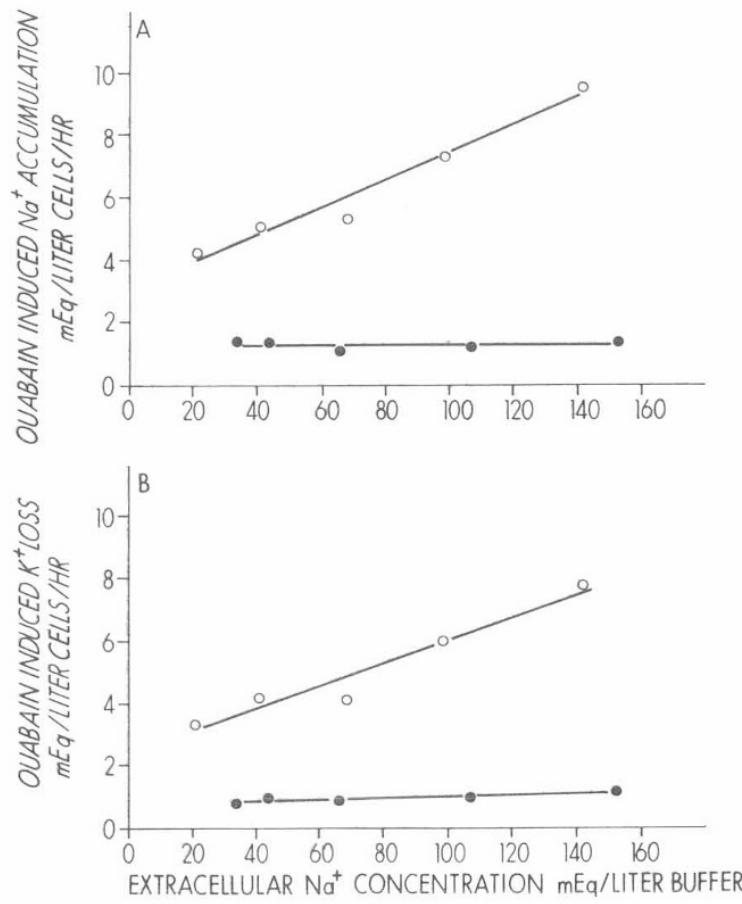

Fig. 3. The effect of various extracellular $\mathrm{Na}^{+}$concentrations on active transport, that is, the net intracellular accumulation of $\mathrm{Na}^{+}(A)$, and loss of $\mathrm{K}^{+}(B)$, induced by $0.1 \mathrm{mM}$ ouabain. Slopes of the regression lines were determined by the method of least squares. The intracellular $\mathrm{Na}^{+}$ concentration in stomatocytes ranged from 10.8 to $13.5 \mathrm{mEq} /$ liter cells. normal erythrocytes; $\mathrm{O}$, stomatocytes.

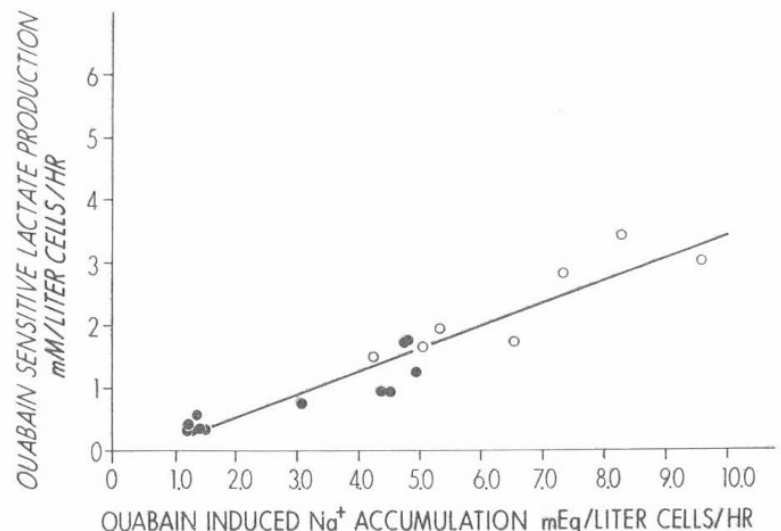

Fig. 4. The relationship between ouabain-sensitive lactate production and active $\mathrm{Na}^{+}$transport, that is, the net intracellular accumulation of $\mathrm{Na}^{+}$induced by $0.1 \mathrm{mM}$ ouabain. Each point represents the mean of duplicate measurements. The line was fitted to the points by the method of least squares. normal erythrocytes; $\mathrm{O}$, stomatocytes. 
$2 \mathrm{BC}$ of several families with stomatocytosis has also been lissociated $(10,12)$. In this study, we have had the opportunity to :valuate more extensively both the isotopic and net movements of $\mathrm{Va}^{+}$and $\mathrm{K}^{+}$in the $\mathrm{RBC}$ of one such patient. Here, the disparity in $\mathrm{Va}^{+}$to $\mathrm{K}^{+}$transport, as measured by isotopes, can be explained by 1 large component of nonactive ${ }^{24} \mathrm{Na}^{+}-{ }^{23} \mathrm{Na}^{+}$exchange. When ictive transport is defined as the net accumulation of intracellular $\mathrm{Va}^{+}$and loss of intracellular $\mathrm{K}^{+}$induced by $0.1 \mathrm{mM}$ ouabain, the ransport ratio is, in fact, normal.

However, there is marked elevation of both $\mathrm{Na}^{+}$and $\mathrm{K}^{+}$ ransport in these stomatocytes. $\mathrm{Na}^{+}$transport is persistently greater than $6.5 \mathrm{mEq} /$ liter cells $/ \mathrm{hr}$, and $\mathrm{K}^{+}$transport is greater than $5.5 \mathrm{mEq} /$ liter cells $/ \mathrm{hr}$, compared with a normal maximal transport of $\mathrm{Na}^{+} 5.0 \mathrm{mEq} /$ liter cells/hr and $\mathrm{K}+3.8 \mathrm{mEq} /$ liter cells/hr. These normal maximal values agree well with those reported by Garay and Garrahan (3). However, the cell population in this patient with stomatocytosis contains $15-25 \%$ reticulocytes, and shows a marked elevation of the $\mathrm{Na}^{+}-\mathrm{K}^{+}$-ATPase (10). We pose this as a potential explanation for the high transport rate seen in this patient's RBC.

The control of transport, however, is less easily explained. These stomatocytes are markedly permeable to both $\mathrm{Na}^{+}$and $\mathrm{K}^{+}$and demonstrate a striking abnormal persistence of maximal transport throughout a range of intracellular $\mathrm{Na}^{+}$between 6 and 45 $\mathrm{mEq} /$ liter cells. A decrease in transport could only be achieved by reducing the gradient across the cell membrane. This maneuver ordinarily has little or no effect on cation transport (4), and $\mathrm{Na}^{+}$ and $\mathrm{K}^{+}$transport is normally responsive only to variation of the intracellular $\mathrm{Na}^{+}$concentration (3). Our data in normal cells are comparable with those published by Garrahan and Glynn (4) and Garay and Garrahan (3). Reticulocyte-rich blood cells which do not have a permeability defect have normal net transport rates and a normal response to elevation of the internal $\mathrm{Na}^{+}(16)$. It is likely that passive cation movement across the plasma membrane in the direction of the cation gradient is so great in these stomatocytes that the transport mechanism responds to this, rather than the actual concentration of $\mathrm{Na}^{+}$within the cell. We could not test whether very low intracellular $\mathrm{Na}^{+}$concentration influenced transport.

The ATP hydrolysis devoted to active cation transport is reflected in the ouabain-sensitive lactate production since approximately $1 \mathrm{~mol}$ ATP is generated for each mole of lactate produced if one assumes little metabolite passage through the RapoportLuebering shunt. Three milliequivalents $\mathrm{Na}^{+}$and $2 \mathrm{mEq} \mathrm{K}+$ are transported against the respective gradients for each millimole of ATP hydrolyzed or ouabain-sensitive lactate produced $(5,17,18)$. Transport-related lactate production in stomatocytes is consistent with this relationship at very high rates of transport, increasing the accuracy of the measurements. Varying the transport rate in these cells demonstrated further that the relationship between transport and transport-related lactate production remained linear. This continuous linear relationship which is independent of the cells' permeability abnormality provides further support that ouabainsensitive net transport is an accurate measurement of true active transport.

\section{SUMMARY}

These studies define further the abnormalities of $\mathrm{Na}^{+}$and $\mathrm{K}^{+}$ movements in stomatocytic RBC. We have found total and ouabain-sensitive transport of radiolabeled $\mathrm{Na}^{+}$and $\mathrm{K}^{+}$to be markedly greater than normal. The increased $\mathrm{Na}^{+}$transport relative to $\mathrm{K}^{+}$transport as measured by isotopes is due to an increased ouabain-independent and ouabain-sensitive ${ }^{24} \mathrm{Na}^{+}$${ }^{23} \mathrm{Na}^{+}$exchange. ${ }^{42} \mathrm{~K}+{ }^{39} \mathrm{~K}+$ exchanges remain relatively normal. Active $\mathrm{Na}^{+}$and $\mathrm{K}^{+}$transport is elevated but remains coupled in a normal ratio.

In contrast to normal RBC, active transport in these stomatocytes is not significantly influenced by variations in intracellular $\mathrm{Na}^{+}$concentration between 6 and $45 \mathrm{mEq} /$ liter cells. However. reducing the gradient across the $\mathrm{RBC}$ membrane by decreasing the extracellular $\mathrm{Na}^{+}$results in a linear fall in active transport. These stomatocytes thus demonstrate an altered control mechanism for active cation transport.

\section{REFERENCES AND NOTES}

1. Blum, S. F., Shohet, S. B., Nathan, D. G.. and Gardner, F. H.: The effect of amphotericin B on erythrocyte membrane cation permeability: Its relation to an in vivo erythrocyte survival. J. Lab. Clin. Med., 73: 980 (1969).

2. Feig, S. A., Segel, G. B., Shohet, S. B., and Nathan, D. G.: Energy metabolism in human erythrocytes. II. Effects of glucose depletion. J. Clin. Invest., 51: 1574 (1972).

3. Garay, R. P.. and Garrahan, P. J.: The interaction of sodium and potassium with the sodium pump in red cells. J. Physiol., 231: 297 (1973).

4. Garrahan, P. J., and Glynn, I. M.: The behavior of the sodium pump in red cells in the absence of external potassium. J. Physiol. 192: 159 (1967).

5. Garrahan, P. J., and Glynn, I. M.: The stoicheiometry of the sodium pump. J. Physiol., 192: 217 (1967).

6. Glynn, I. M.: Sodium and potassium movements in human red cells. J. Physiol.. 134: 278 (1956).

7. Goldstein, A.: Biostatistics-An Introductory Text (The MacMillan Company. New York, 1964).

8. Harris, E. J.: Linkage of sodium and potassium active transport in human erythrocytes. Active transport and secretion. Symp. Soc. Exp. Biol., 8: 229 (1954).

9. Hohorst, H. J.: L-(+)-Lactate. Determination with lactic dehydrogenase and DPN. In: H. U. Bergmeyer: Methods of Enzymatic Analysis, p. 266 (Academic Press, New York, 1963).

10. Miller, D. R., Rickles, F. R., Lichtman, M. A., LaCelle, P. L., Bates, J., and Weed, R. I.: A new variant of hereditary hemolytic anemia with stomatocytosis and erythrocyte cation abnormality. Blood, 38: 184 (1971).

11. Murphy, J. R.: Erythrocyte metabolism. V. Active cation transport and glycolysis. J. Lab. Clin. Med., 61: 567 (1963).

12. Oski, F. A., Naiman, J. L., Blum, S. F., Zarkowsky, H. S., Whaun, J., Shohet, S. B., Green, A., and Nathan, D. G.: Congenital hemolytic anemia with high-sodium, low-potassium red cells. New Engl. J. Med., 280: 909 (1969).

13. Post, R. L., and Jolly, P. C.: The linkage of sodium, potassium and ammonium active transport across the human erythrocyte membrane. Biochim. Biophys. Acta, 25: 118 (1957).

14. Sachs, J. R.: Recoupling the Na-K pump. J. Clin. Invest., 51: 3244 (1972)

15. Schrier, S. L.: Organization of enzymes in human erythrocyte membranes. Amer. J. Physiol., 210: 139 (1966).

16. Segel, G. B., Feig S. A.. Glader, B. E., Müller, A., Dutcher, P., and Nathan, D. G.: Energy metabolism in human erythrocytes: The role of phosphoglycerate kinase in cation transport. Blood, 46: 271 (1975).

17. Sen, A. K., and Post, R. L.: Stoichiometry and localization of adenosine triphosphate-dependent sodium and potassium transport in the erythrocyte. J. Biol. Chem., 239: 345 (1964).

18. Whittam, R., and Ager, M. E.: The connection between active cation transport and metabolism in erythrocytes. Biochem. J., 97: 214 (1965).

19. We most gratefully acknowledge the advice and constructive criticism of $\mathrm{Dr}$. Marshall Lichtman and the assistance of Miss Frances Hadlow in the preparation of this manuscript.

20. Dr. Segel is the recipient of United States Public Health Service Research Career Development Award CA00019.

21. This research was supported in part by United States Public Health Service Grant CA 14576 and the University of Rochester GRSG Grant 5-29745.

22. Requests for reprints should be addressed to: George B. Segel, M.D., Assistant Professor of Pediatrics and of Medicine, Department of Pediatrics, University of Rochester School of Medicine, Strong Memorial Hospital, 601 Elmwood Ave., Rochester, N. Y. 14642 (USA).

23. Accepted for publication July 28, 1975. 